\title{
Potret Industri Halal Indonesia: Peluang dan Tantangan
}

\author{
Muhammad Anwar Fathoni ${ }^{1}$, Tasya Hadi Syahputri ${ }^{2}$ \\ ${ }_{1,2}^{1,2}$ Fakultas Ekonomi dan Bisnis, Universitas Pembangunan Nasional Veteran Jakarta \\ *Email korespondensi: mfathoni@upnvj.ac.id
}

\begin{abstract}
This study aims to explain the positioning of Halal Industry in Indonesia. This study also identify opportunities and challenges in its development. The method used in this study is descriptive-qualitative method with a phenomenological approach. The data obtained were analyzed using qualitative analysis through data reduction, categorization and verification. This research found that Indonesia has potential to develop Halal Industry in various sectors, especially halal food, halal travel, halal fashion and halal finance. The development of Halal Industry also has the potential to increase national economic growth. However, Indonesia must face various challenges such as the low of halal awareness, low of local product competitiveness and problems in implementing the Halal Product Guarantee Regulation.
\end{abstract}

Abstract

Keywords: Halal Industry, Halal Product Guarantee, Economic Growth

Saran Sitasi: Fathoni, M. A., Syahputri, T. H. (2020). Potret Industri Halal Indonesia: Peluang dan Tantangan. Jurnal Ilmiah Ekonomi Islam, 6(03), 428-435. doi: http://dx.doi.org/10.29040/jiei.v6i3.1146

DOI: http://dx.doi.org/10.29040/jiei.v6i3.1146

\section{PENDAHULUAN}

Industri halal menjadi tren dunia saat ini. Hal ini terbukti dari prospek industri halal yang terus tumbuh dari tahun ke tahun. Menurut laporan dari State of The Global Islamic Report (2019), ada sekitar 1,8 miliar penduduk muslim yang menjadi konsumen industri halal. Peluang konsumen dalam industri halal meningkat sebesar 5,2\% setiap tahunnya dengan total pengeluaran konsumen yang mencapai USD 2,2 triliun. Jumlah ini diperkirakan akan terus meningkat tiap tahunnya. Proyeksi dari Compound Annual Growth Rate (CAGR) industri halal akan meningkat hingga mencapai 6,2\% dalam kurun waktu 2018 hingga 2024. Total dana yang dihabiskan oleh konsumen industri halal juga akan meningkat hingga mencapai USD 3,2 triliun pada tahun 2024. Dari data tersebut dapat kita lihat bahwa industri halal memiliki prospek yang sangat cerah ke depannya(State of Global Islamic Economy Report 2019)

Indonesia adalah salah satu negara yang memiliki potensi besar untuk mengembangkan industri halal. Tentu saja, potensi yang besar ini merupakan implikasi dari banyaknya jumlah penduduk muslim di Indonesia. Indonesia menyumbang $12,7 \%$ populasi muslim di dunia. Bila dilihat dari jumlahnya, pada tahun 2020 diperkirakan sebanyak 229 juta penduduk muslim tinggal di Indonesia. Total populasi di Indonesia diperkirakan mencapai 273 juta jiwa, sehingga jumlah penduduk muslim setara dengan $87,2 \%$ total populasi di Indonesia (World Population Review, 2020). Populasi muslim yang besar ini membuat permintaan terhadap produk halal juga besar. Indonesia disebut sebagai perwujudan dari pasar industri halal dunia. Bahkan, total spending yang dihabiskan Indonesia untuk belanja produk halal sebesar USD 218,8 miliar pada tahun 2017 (Kementerian Keuangan Republik Indonesia 2019)

Industri halal memiliki peran strategis dalam meningkatkan perekonomian. Maka, sudah seharusnya industri halal dikembangkan di Indonesia. Industri halal telah menyumbang USD 3,8 miliar terhadap Produk Domestik Bruto (PDB) Indonesia setiap tahunnya. Selain itu, industri halal juga telah menyumbang USD 1 miliar investasi dari investor asing dan membuka 127 ribu lapangan pekerjaan per tahunnya. Bila dioptimalkan lagi, industri halal dapat meningkatkan nilai ekspor dan cadangan devisa negara (Kementerian Keuangan Republik Indonesia 2019). Maka, sudah semestinya Indonesia mulai 
mengembangkan industri halal agar bisa membangun perekonomian secara maksimal.

Namun sangat disayangkan bahwa potensi industri halal yang dimiliki Indonesia belum tergarap sepenuhnya. Data di lapangan menunjukkan masih sedikit sekali output industri halal yang ada di Indonesia. Berdasarkan penilaian yang tercantum pada State of The Global Islamic Report (2019), Indonesia hanya menempati peringkat ke-5 dalam kategori Top 15 Global Islamic Economy Indicator dengan skor sebesar 49. Sementara itu, bila dilihat dari berbagai sektor industri halal, Indonesia menempati peringkat ke-5 dalam Top 10 Islamic Finance, peringkat ke-4 dalam Top 10 Muslim-Friendly Travel, dan peringkat ke-3 dalam Top 10 Modest Fashion. Sementara itu, untuk sektor Halal Food, Media and Recreation dan Pharma and Cosmetics, Indonesia tidak masuk ke dalam peringkat 10 besar (State of Global Islamic Economy Report 2019)

Tentu saja hal ini membuat kita miris, mengingat Indonesia adalah negara dengan jumlah penduduk muslim terbanyak di dunia. Jumlah penduduk muslim yang begitu banyak ternyata belum bisa menjadikan Indonesia sebagai negara pemasok kebutuhan komoditas halal di dunia. Hal ini terlihat dari belum mampunya Indonesia untuk masuk ke dalam Top 10 di semua sektor industri halal. Bahkan, untuk halal food yang merupakan kebutuhan dasar seorang muslim Indonesia belum bisa memenuhinya. Jika kita lihat, terdapat ketimpangan yang begitu besar antara potensi dengan realita industri halal yang terjadi di lapangan.

Ketimpangan ini membuat Indonesia masih berkutat sebagai konsumen pasar industri halal dunia. Sudah saatnya Indonesia bangkit dan menjadi role model dalam industri halal dunia. Bahkan pemerintah sudah menyuarakan cita-cita bahwa Indonesia bisa dan sangat mungkin menjadi kiblat industri halal dunia. Untuk itu, ketimpangan ini harus dihilangkan guna mewujudkan cita-cita tersebut. Dengan segala potensi yang dimiliki oleh Indonesia, sudah seharusnya industri halal semakin dioptimalkan demi membangun perekonomian dan mensejahterakan kehidupan masyarakat, mengingat peran industri halal yang sangat strategis dalam perekonomian.

Berdasarkan latar belakang yang telah dijelaskan di atas, penulis tertarik untuk mengangkat penelitian tentang Industri Halal dalam Perekonomian Indonesia. Melalui penelitian ini, penulis berharap akan memberikan kontribusi potret industri halal di
Indonesia yang memiliki peluang untuk dikembangkan. Tidak hanya itu, hasil dari penelitian ini juga diharapkan dapat memberikan penjelasan sektor industri apa saja yang memiliki kekuatan dan potensi besar dalam membantu perekonomian Indonesia.

\section{METODE PENELITIAN}

Penelitian ini merupakan penelitian deskriptif kualitatif dengan pendekatan fenomenologi. Penelitian ini merupakan penelitian kepustakaan yang menggunakan data sekunder yang didapatkan melalui artikel ilmiah maupun dokumen lainnya yang relevan. Data yang didapatkan tersebut kemudian dianalisis dengan menghasilkan penjelasan deskriptif berupa kata-kata, gambar maupun simbol yang dihubungkan dengan objek penelitian ini.

Analisis data dalam penelitian ini dilakukan dalam tiga tahapan, yaitu reduksi data, kategorisasi data, dan verifikasi data. Reduksi data dalam penelitian ini dilakukan dengan menyeleksi semua data melalui pemotongan dan penyederhanaan data yang ada sesuai dengan topik penelitian. Selanjutnya dilakukan kategorisasi data yang sudah direduksi sesuai dengan topik penelitian yaitu peran Industri Halal dalam Perekonomian Indonesia. Tahapan terakhir adalah verifikasi data untuk menarik konklusi yang merupakan interpretasi peneliti terhadap data. Verifikasi dilakukan dengan teknik triangulasi, yaitu mengkomparasikan antara satu sumber data dengan sumber data lainnya (Neuman and Djamba 2014).

\section{HASIL DAN PEMBAHASAN}

\subsection{Peran Industri Halal terhadap Pertumbuhan Ekonomi}

Industri halal terus menunjukkan pertumbuhan yang positif setiap tahunnya. Pertumbuhan ini tentunya memberikan kontribusi yang positif terhadap perekonomian Indonesia. Kontribusi tersebut bisa dilihat melalui Produk Domestik Bruto (PDB). Ekonomi syariah sudah terbukti memberikan kontribusi terhadap Produk Domestik Bruto (PDB) sebesar USD 3,8 miliar setiap tahunnya (Kementerian Keuangan Republik Indonesia 2019). Kontribusi terhadap PDB ini tercermin dari konsumsi masyarakat Indonesia serta kegiatan ekspor dan impor terhadap produk halal.

Konsumsi masyarakat Indonesia terhadap produk halal sangat besar, bahkan termasuk yang terbesar di dunia. Tercatat pada tahun 2017 total konsumsi 


\section{Jurnal Ilmiah Ekonomi Islam, 6(03), 2020, 430}

produk halal di Indonesia sebesar USD 200 miliar atau lebih dari $36 \%$ total konsumsi rumah tangga. Jumlah ini juga setara dengan 20\% PDB Indonesia (Kementerian Keuangan Republik Indonesia 2019) Konsumsi produk halal ini akan terus tumbuh dengan rata-rata pertumbuhan 5,3\%. Pada tahun 2025, diperkirakan tingkat konsumsi produk halal Indonesia akan mencapai USD 330,5 miliar (Tim Publikasi Katadata 2020). Bappenas menyatakan bahwa total konsumsi yang besar ini mayoritas berasal dari produk impor (Akbar, 2019). Namun, bila kita meningkatkan produksi pada sektor industri halal, kita bisa menekan angka defisit pada neraca perdagangan (Kementerian Keuangan Republik Indonesia 2019). Bahkan, bukan hal yang mustahil bila kita juga bisa melakukan peningkatan ekspor produk halal.

Dari segi eskpor, industri halal sangat berpeluang menambah nilai ekspor Indonesia. Nilai ekspor yang bisa dihasilkan dari industri halal berkisar pada USD 5,1 miliar hingga USD 11 miliar setiap tahunnya. Pada tahun 2018, industri halal telah menghasilkan USD 7,6 miliar. Indonesia memiliki halal export opportunity produk halal sebesar 3,8\% secara global (Indonesia Halal Lifestyle Center 2019). Angka ini bisa ditingkatkan lagi dengan cara meningkatkan kualitas produk halal yang diekspor. Selain itu, penetapan harga yang kompetitif dirasa penting agar produk kita bisa bersaing dengan produk dari negara lain. Jika produk halal dari Indonesia sudah bisa bersaing di pasar dunia, maka tentu saja Indonesia bisa menjadi kiblat industri halal dunia.

Berbicara mengenai peningkatan ekspor, sudah pasti di dalamnya terdapat peningkatan produksi. Untuk meningkatkan produksi, suatu perusahaan membutuhkan peningkatan jumlah tenaga kerja. Maka, terjadi hubungan positif antara ekspor dengan penyediaan tenaga kerja. Industri halal juga memiliki pengaruh ekonomi terhadap lapangan pekerjaan. Dari segi lapangan pekerjaan, industri halal mampu membuka 170.000-330.000 lapangan pekerjaan (Indonesia Halal Lifestyle Center 2019). Jika industri halal terus tumbuh, maka jumlah ini bisa lebih besar lagi.

Kegiatan ekspor merupakan bagian dari perdagangan internasional. Dalam perdagangan internasional diperlukan pembiayaan yang berasal dari cadangan devisa. cadangan devisa sendiri diartikan sebagai nilai aktiva bersih luar negeri pemerintah serta bank-bank devisa yang harus dijaga untuk memenuhi keperluan transaksi internasional
(Purba, 2016). Cadangan devisa menjadi indikator untuk mengetahui sejauh mana kemampuan suatu negara untuk melakukan perdagangan internasional. Posisi cadangan devisa dapat dilihat dari neraca pembayaran. Maka bisa dikatakan bahwa cadangan devisa dipengaruhi hal-hal yang terdapat neraca pembayaran (Erwina, dkk, 2018)

Salah satu faktor yang mempengaruhi cadangan devisa dipengaruhi adalah nilai ekspor bersih. Nilai ekspor bersih tercantum di neraca pembayaran pada bagian neraca transaksi berjalan dan neraca modal. Nilai ekspor bersih sendiri dipengaruhi oleh perekonomian dalam dan luar negeri beserta kurs valuta asing. Kondisi perekonomian Indonesia yang belum stabil sangat mempengaruhi jumlah cadangan devisa (Sayoga dan Tan 2017). Berikut ini adalah data mengenai cadangan devisa dan nilai ekspor dari tahun 2015 hingga 2019.

Tabel 1. Data Cadangan Devisa dan Ekspor dari Tahun 2015-2019

\begin{tabular}{|c|c|c|}
\hline Tahun & $\begin{array}{c}\text { Cadangan Devisa } \\
\text { (Juta USD) }\end{array}$ & $\begin{array}{c}\text { Ekspor (Juta } \\
\text { USD) }\end{array}$ \\
\hline 2015 & 105.931 & 150.366 \\
\hline 2016 & 116.362 & 145.186 \\
\hline 2017 & 130.196 & 168.828 \\
\hline 2018 & 120.654 & 180.012 \\
\hline 2019 & 123.800 & 167.497 \\
\hline
\end{tabular}

Sumber: BPS dan Kementerian Perdagangan (diolah)

Industri halal dengan segala potensinya dapat kita gunakan untuk mendorong peningkatan nilai cadangan devisa. Ada beberapa cara yang bisa kita lakukan. Pertama, meningkatkan nilai ekspor industri halal. Komoditas halal yang sangat berpotensi untuk diekspor oleh Indonesia adalah makanan halal dan busana muslim. Seperti yang telah dijelaskan sebelumnya, untuk mendorong nilai ekspor maka langkah yang harus dilakukan adalah meningkatkan produksi komoditas disertai dengan peningkatan kualitas serta penetapan harga yang kompetitif.

Kedua, meningkatkan potensi pariwisata halal. Pariwisata halal adalah sektor yang paling berpotensi untuk mendorong peningkatan cadangan devisa. Terlebih Indonesia telah mendapat banyak penghargaan dalam konteks wisata halal. Maka, hal yang harus kita lakukan adalah dengan meningkatkan kualitas pariwisata halal Indonesia dengan menyusun strategi yang tepat sasaran. Strategi yang dapat kita lakukan yaitu dengan menguatkan integrasi paket wisata, meningkatkan kualitas sumber daya manusia 


\section{Jurnal Ilmiah Ekonomi Islam, 6(03), 2020, 431}

(SDM), membuat regulasi yang mendukung dan memanfaatkan perkembangan teknologi (Tim Publikasi Katadata 2020).

Ketiga, meningkatkan peran industri keuangan syariah dalam rangka mewujudkan inklusi keuangan. Industri keuangan syariah bisa digunakan untuk mendukung akses permodalan Usaha Mikro Kecil Menengah (UMKM) yang bergerak di sektor halal melalui pembiayaan. Modal ini bisa digunakan untuk ekspansi usaha. Bayangkan saja, bila ada banyak UMKM yang mengekspansi usahanya, maka kegiatan produksi akan meningkat. Peningkatan produksi ini bisa membawa komoditas halal Indonesia menuju perdagangan internasional.

Di samping itu, program inklusi keuangan juga memberikan kemudahan dalam transaksi pembayaran bagi UMKM. Jika semakin banyak UMKM yang bertransaksi melaui industri keuangan syariah, maka akan terjadi peningkatan market share industri keuangan syariah. Dampaknya, industri keuangan syariah akan semakin menguat sehingga dapat memberikan dampak yang lebih luas untuk mensejahterakan masyarakat.

Dari semua peluang yang telah dipaparkan di atas, kita memerlukan dukungan dari semya pihak untuk menumbuhkembangkan industri halal. Baik pemerintah maupun masyarakat. Dukungan dari pemerintah bisa berupa regulasi mengenai produk dan industri halal serta sertifikasi halal. Regulasi dan sertifikasi halal membantu pelaku usaha, terutama UMKM agar produk-produk tersebut menembus pasar ekspor. Sementara itu, dukungan dari masyarakat berupa upaya untuk meningkatkan halal awareness dan membeli produk halal dari industri dalam negeri. Dengan adanya sinergi dan kerja sama dari semua pihak, cita-cita "Indonesia sebagai kiblat industri halal dunia" bukanlah hal yang mustahil untuk dicapai.

\subsection{Potensi Industri Halal di Indonesia}

Industri halal memiliki potensi yang sangat besar di Indonesia. Hal ini merupakan implikasi dari jumlah penduduk muslim Indonesia yang sangat banyak. Potensi industri halal Indonesia bisa kita lihat dari beberapa sektor, yaitu sektor makanan halal, sektor keuangan syariah, sektor wisata halal, dan sektor busana muslim. Berikut ini adalah penjelasan potensi dari masing-masing sektor.

Pertama, sektor makanan halal. Makanan halal merupakan kebutuhan dasar seorang muslim. Kebutuhan dasar ini harus terpenuhi agar seorang muslim dapat melanjutkan hidupnya. Bila kita lihat dari jumlah penduduk muslim di Indonesia, tentu saja Indonesia punya potensi dalam sektor ini. Potensi yang benar-benar terlihat adalah potensi pasar yang sangat menjanjikan. Pada tahun 2019, Indonesia menghabiskan USD 173 miliar untuk konsumsi makanan halal. Hal ini menjadikan Indonesia sebagai pasar terbesar makanan dan minuman halal di dunia (State of Global Islamic Economy Report 2019).

Dukungan pemerintah juga menjadi potensi besar industri makanan halal di Indonesia. Dukungan pemerintah ini terlihat dari pembentukan Badan Penyelenggara Jaminan Produk Halal (BPJPH) sebagai amanat dari Undang-Undang Nomor 33 Tahun 2014 Tentang Jaminan Produk Halal. BPJPH disahkan pada tanggal 27 Oktober 2017 dan memiliki kedudukan di bawah Kementerian Agama. Pembentukan BPJPH telah mentransformasi penyelenggaraan jaminan produk halal di Indonesia dari yang awalnya bersifat sukarela (voluntary) menjadi kewajiban (mandatory). Hal ini dilakukan dalam rangka memberi keamanan dan kenyamanan kepada konsumen muslim serta untuk melejitkan industri halal di Indonesia, khususnya industri makanan halal (Aziz, dkk, 2019)

Kedua, sektor keuangan syariah. Sektor keuangan syariah menjadi gerbang pembuka industri halal di Indonesia. Semenjak terbentuknya Bank Muamalat Indonesia pada tahun 1992, sektor keuangan syariah telah membawa perkembangan yang cukup baik bagi industri keuangan syariah. Aset keuangan syariah terus mengalami pertumbuhan setiap tahunnya. Pada tahun 2018 , aset keuangan syariah mengalami kenaikan sebesar $13,97 \%$ (yoy) menjadi Rp1.287,65 triliun (Otoritas Jasa Keuangan 2019). Indonesia menempati peringkat ketujuh dalam pasar aset keuangan Islam di dunia dengan total nilai aset sebesar USD 86 miliar. Indonesia juga menempati urutan ke-5 dalam Top 10 Islamic Finance (State of Global Islamic Economy Report 2019). Pada tahun 2019, market share industri keuangan mencapai angka $8,69 \%$. Angka tersebut merupakan total dari market share perbankan syariah sebesar $5,94 \%$ ditambah market share Industri Keuangan Non Bank (IKNB) sebesar 2,75\% (CNN Indonesia 2019). Pertumbuhan sektor keuangan ini mencerminkan potensi sektor keuangan syariah yang cukup besar di Indonesia.

Ketiga, sektor wisata halal. Indonesia merupakan negara yang memiliki keragaman budaya serta kaya akan sejarah dan tradisi-tradisi keagamaan. Selain itu, indahnya panorama alam di Indonesia serta 
masyarakatnya yang ramah menjadi daya tarik Indonesia dalam bidang pariwisata. Bila dikaitkan dengan wisata halal, potensi yang dimiliki Indonesia sangat besar. Ada banyak objek wisata yang bisa dikunjungi oleh halal traveller, diantaranya masjid, keraton, makam, benda-benda pusaka, hingga kuliner halal (Jaelani 2017)

Potensi wisata halal Indonesia mendapat apresiasi yang luar biasa, sebab Indonesia berhasil meraih peringkat pertama bersama Malaysia pada kategori utama Top 10 OIC Destinations dengan skor 78. Selain itu, Indonesia juga meraih peringkat pertama dua kategori lainnya, seperti Top 10 Destinations-Communications dan Top 10 Destinations-Services (Crescent Rating 2019). Selain itu, Indonesia juga meraih peringkat ke-4 dalam Top 10 Muslim-Friendly Travel (State of Global Islamic Economy Report 2019). Pemerintah melalui Kementerian Pariwisata dan Ekonomi Kreatif juga telah mengembangkan sepuluh destinasi wisata ramah muslim di Indonesia, yaitu Aceh, Sumatera Barat, Riau dan Kepulauan Riau, DKI Jakarta, Jawa Barat, Jawa Tengah, Yogyakarta, Jawa Timur, Nusa Tenggara Barat, serta Sulawesi Selatan (Tim Publikasi Katadata 2020).

Terdapat beberapa faktor yang membuat potensi wisata halal di Indonesia begitu besar, yaitu: pertumbuhan populasi muslim yang relatif cepat, pertumbuhan middle-class income penduduk muslim yang juga cukup besar, banyaknya populasi muslim yang masih muda dan gemar melakukan travelling, akses informasi pariwisata yang berkembang pesat, fasilitas dan layanan yang ramah dan memuaskan, adanya Ramadhan travel yang menarik minat wisatawan, dan bisnis travel yang semakin berkembang dan cepat tanggap terhadap kebutuhan wisawatan (Alwafi Ridho Subarkah 2018).

Keempat, sektor busana muslim. Potensi busana muslim di Indonesia juga tidak kalah besarnya. Industri busana muslim terus mengalami pertumbuhan dari tahun ke tahun. Pada tahun 2019, ekspor sektor busana muslim telah menembus angka USD 9,2 miliar atau setara dengan $9,8 \%$ total ekspor dari industri pengolahan. Bila dilihat dari pasar domestik, konsumsi dari produk busana muslim sudah mencapai angka USD 20 miliar dengan laju pertumbuhan ratarata 18,2\% (Redaksi FIN 2019). Indonesia menepati posisi ke-3 dalam Top 10 Modest Fashion dan Top 10 Fashion Muslim Consumer Markets dengan total spending sebesar USD 21 miliar (State of Global
Islamic Economy Report 2019). Selain itu, adanya dukungan dan peran pemerintah, pengesahan UndangUndang Nomor 33 Tahun 2014 Tentang Jaminan Produk Halal, maraknya desainer busana muslim dan ajang perlehatan busana muslim, serta respon masyarakat yang positif membuat potensi ini semakin mungkin untuk dikembangkan (A. I. Faried 2019; Aan Nasrullah 2018).

Disamping potensi di masing-masing sektor, perkembangan teknologi juga menjadi potensi industri halal di Indonesia secara umum. Adanya teknologi mendorong peningkatan sosialisasi dan promosi industri halal di Indonesia. Selain itu, perkembangan teknologi juga membuat pembuatan produk industri halal menjadi lebih efektif dan efisien (Faried, 2019; Jaelani, 2017).

\subsection{Tantangan Industri Halal di Indonesia}

Dalam mengembangkan potensi industri halal di Indonesia, tentunya kita akan mendapatkan tantangan. Tantangan ini bisa berasal dari segi eksternal dan dari segi internal. Dari segi eksternal, tantangan yang dihadapi Indonesia adalah: pertama, banyaknya negara pesaing (Permana 2019). Negara-negara pesaing tersebut diantaranya adalah Malaysia, Brunei Darussalam, Turki, Pakistan, Qatar, Uni Emirat Arab, dan lain sebagainya. Bahkan, ada negara pesaing yang termasuk ke dalam negara non-muslim. Negaranegara ini diantaranya Australia, Thailand, Singapura, United Kingdom, Italia, dan lain sebagainya. Agar tidak ketinggalan, Indonesia harus bisa memanfaatkan dengan baik potensi yang dimilikinya. Bila tidak, maka Indonesia hanya akan menjadi konsumen di pasar yang besar dan menjanjikan ini.

Tantangan dari eskternal ini juga berpengaruh terhadap konsumsi produk dalam negeri. Jika ada banyak produk asing masuk ke Indonesia, maka konsumsi produk Indonesia akan berkurang. Dampaknya, neraca perdagangan akan mengalami defisit karena lebih banyak impor yang masuk ketimbang ekspor. Maka, solusi dari masalah ini adalah keseriusan pemerintah dalam menegakkan hukum kepabeanan (Pryanka, 2018). Kita membutuhkan proteksi untuk melindungi produk lokal. Kebijakan proteksi ini harus bisa menekan angka impor, namun tidak membuat negara pengimpor "tersinggung". Tujuannnya agar produk lokal terproteksi sekaligus tetap menjaga hubungan internasional.

Kedua, belum adanya sertifikat halal yang berlaku secara global. Hal ini disebabkan belum 


\section{Jurnal Ilmiah Ekonomi Islam, 6(03), 2020, 433}

adanya konsensus yang dilakukan oleh negara-negara di dunia mengenai standarisasi sertifikat halal intenasional. Setiap negara memiliki kriteria tersendiri dalam penetapan sertifikasi halal. Kriteria ini belum tentu diterima oleh negara lain. Maka, tercipta ketidakteraturan dalam sertifikasi halal. Tentu saja, hal ini bisa berdampak kepada kepercayaan konsumen saat produk tersebut diekspor ke negara lain (Randeree 2019). Oleh sebab otu, perlu diadakan pertemuan di antar negara-negara di dunia untuk membahas standarisasi sertifikasi halal ini. Setidaknya, langkah ini bisa dimulai oleh Organisasi Kerja Sama Islam (OKI).

Sementara itu, tantangan internal yang dialami Indonesia yaitu: pertama, kurangnya halal awareness pada masyarakat Indonesia. Selain itu, pemahaman masyarakat Indonesia terhadap konsep halal masih dirasa kurang. Ada banyak masyarakat Indonesia yang menganggap bahwa semua produk di pasar adalah produk halal (Pryanka, 2018). Halal awareness memiliki keterkaitan dengan religiusitas dan pengetahuan mengenai konsep halal. Berdasarkan penelitian yang dilakukan oleh (Nusran, dkk, 2018), religiusitas memiliki pengaruh yang lebih besar terhadap perilaku konsumsi produk halal dibanding pengetahuan terhadap suatu produk halal. Ada juga penelitian yang dilakukan oleh (Kartika, 2020; Kurniawati dan Savitri, 2019) yang menyatakan bahwa halal awareness dipengaruhi oleh tingkat keyakinan agama, alasan kesehatan, label/logo halal, dan tingkat eksposur yang baik. Selain itu, berdasarkan penelitian yang dilakukan oleh (Yasid, $\mathrm{dkk}$, 2016), halal awareness dipengaruhi oleh kepercayaan agama, identitas diri dan paparan media.

Maka, untuk meningkatkan halal awareness di Indonesia, kuncinya adalah dengan melakukan sosialisasi. Sosialisasi harus dilakukan secara terusmenerus secara langsung ataupun tidak langsung. Sosialisasi secara langsung bisa dilakukan dengan membuat kajian keagamaan tentang konsep halal, mengadakan seminar bertemakan industri halal, mengadakan kunjungan ke lembaga pendidikan, serta mengadakan event dan pameran industri halal. Sementara itu, sosialisasi secara tidak langsung dapat dilakukan dengan perantara berbagai media. Pada media cetak, sosialisasi bisa dilakukan dengan membuat artikel pada koran dan majalah, membuat buku dan komik mengenai konsep halal seperti yang dilakukan Majelis Ulama Indonesia (MUI) (Nusran, 2018). Melalui media elektronik, sosialisasi bisa dilakukan dengan membuat siaran mengenai konsep dan industri halal. Sosialisasi juga bisa dilakukan melalui media siber, seperti dengan membuat konten pada website dan media sosial, membuat challenge di media sosial, serta melakukan siaran online di media sosial.

Kedua, adanya problematika dari UndangUndang Nomor 33 Tahun 2014 Tentang Jaminan Produk Halal. Sejak ditetapkan tahun 2014, penerapan Undang-Undang Jaminan Produk Halal (UU JPH) baru mulai berlaku pada 17 Oktober 2019. Setelah ditetapkan pada tahun 2019, UU JPH ini masih tetap membutuhkan waktu karena kewajiban sertifikasi halal dilakukan secara bertahap (Fajaruddin, 2018). Selain itu, ada berbagai problematika yang membuat pelaksanaan undang-undang ini belum efektif. Problematika tersebut diantaranya adalah keterlambatan pemerintah dalam mengeluarkan Peraturan Pemerintah (PP) mengenai pelaksanaan UU JPH. Menurut UU JPH, PP mengenai pelaksanaan UU JPH dikeluarkan paling lambat dua tahun setelah penetapan UU JPH, yakni tahun 2016. Namun realitanya, pemerintah baru mengeluarkan PP ini pada tahun 2019 yang artinya pemerintah terlambat tiga tahun dalam mengeluarkan PP. Bisa dikatakan bahwa pemerintah melanggar ketentuan hukum dalam pelaksanaan UU JPH (Kusnadi, 2019).

Keterlambatan juga terjadi dalam penerbitan peraturan menteri. Pelaksanaan UU JPH membutuhkan peraturan menteri sebagai peraturan turunan untuk menunjang pelaksanaan UU JPH. Peraturan menteri yang harus dikeluarkan yaitu peraturan menteri agama tentang penyelenggaraan jaminan produk halal, produk yang belum bersertifikat halal dan tahapan jenis produk yang wajib bersertifikat halal, kriteria tertentu dalam pengharaman produk, dan jenis produk yang wajib bersertifikat halal. Ada juga peraturan menteri yang harus dikeluarkan menteri keuangan terkait biaya sertifikasi halal. Dari beberapa peraturan menteri ini belum ada satu pun peraturan menteri yang dikeluarkan, padahal UU JPH sudah berlaku. Maka dari segi subtansi hukum, kerangka normatif UU JPH masih belum sempurna (Kusnadi, 2019).

Problematika lain yang ditemukan dalam UU JPH adalah UU JPH sangat berpotensi untuk menyusahkan pelaku usaha serta menghambat laju pertumbuhan ekonomi. Dalam Pasal 21 ayat (1) dijelaskan bahwa harus ada pemisahan pada lokasi, tempat dan alat proses produk halal (PPH). Pemisahan 
ini akan memberatkan para pelaku usaha, terutama pelaku UMKM karena menimbulkan biaya yang tidak perlu. Selanjutnya, dalam hal menghambat laju pertumbuhan ekonomi disebutkan bahwa harus ada pengakuan sertifikasi halal Indonesia di negara tujuan ekspor produk. Bila tidak, maka produk Indonesia tidak dapat masuk ke negara tersebut dan demikian sebaliknya. Tentu saja hal ini bisa menghambat kegiatan perdagangan internasional yang berimbas pada terhambatnya laju pertumbuhan ekonomi (Kusnadi, 2019). Potensi penghambat ini tentu harus diantisipasi oleh otoritas terkait dengan lebih gencar dalam melakukan kerjasama bilateral maupun multilateral guna memperlancar arus perdagangan Indonesia. Jangan sampai aturan yang telah disahkan sebagai Undang-Undang tersebut justru menghambat perdagangan internasional Indonesia.

Ketiga, rendahnya kesadaran masyarakat Indonesia untuk berkompetisi. Masuknya berbagai produk halal dari luar negeri membuat produk lokal Indonesia harus bersaing agar tetap eksis. Namun sayangnya, kesadaran masyarakat Indonesia untuk berkompetisi masyarakat Indonesia masih rendah. Maka tidak mengherankan jika saat ini Indonesia lebih cenderung menjadi konsumen industri halal (Permana, 2019; Pryanka, 2018). Bahkan, data State of Global Islamic Report pada tahun 2018 menyebutkan bahwa Indonesia menempati urutan pertama negara dengan pengeluaran untuk makanan halal terbesar senilai USD 170 miliar. Ironisnya, angka fantastis ini ternyata tidak berbanding lurus dengan prestasi sebagai negara produsen makanan halal, dimana Indonesia pada tahun yang sama tidak masuk sebagai 10 besar negara produksi makanan halal. Fenomena ini tentunya harus menjadi perhatian bersama agar Indonesia tidak hanya sebagai pasar industri halal yang konsumtif, namun Indonesia harus dapat mengoptimalkan berbagai peluang yang ada untuk menjadi negara produktif di bidang industri halal.

\section{KESIMPULAN}

Indonesia memiliki potensi yang luar biasa untuk mengembangkan industri halal. Potensi tersebut di antaranya adalah jumlah penduduk muslim yang melimpah hingga diproyeksikan mencapai 256 juta jiwa pada tahun 2050, pertumbuhan berbagai sektor industri halal khususnya sektor keuangan, pariwisata dan fashion, mulai diakuinya prestasi Indonesia di mata dunia, kondisi geografis Indonesia serta bonus demografinya, perkembangan teknologi, serta pengesahan Undang-Undang Jaminan Produk Halal nomor 33 tahun 2014.

Potensi tersebut dapat mendorong terjadinya pertumbuhan ekonomi melalui peningkatan nilai ekspor dan cadangan devisa. Namun di sisi lain, Indonesia juga memiliki tantangan dalam mengembangkan industri halal ini. Tantangan yang dihadapi Indonesia berasal dari eksternal dan internal.

Dari sudut pandang eksternal, tantangan yang dihadapi Indonesia yaitu banyaknya negara pesaing, belum adanya sertifikat halal yang berlaku secara internasional. Sedangkan dari sudut pandang internal, tantangan yang dihadapi Indonesia adalah kurangnya halal awareness pada masyarakat Indonesia, adanya problematika dalam pelaksanaan Undang-Undang Jaminan Produk Halal dan rendahnya kesadaran masyarakat Indonesia untuk berkompetisi. Melalui penelitian ini, diharapkan banyak kalangan yang semakin sadar akan pentingnya industri halal sehingga dapat mendukung upaya untuk memajukan industri halal Indonesia.

Dengan melihat potensi dan tantangan tersebut, pemerintah disarankan untuk lebih menggalakkan edukasi kepada pelaku usaha tentang pentingnya menjaga dan menjamin kualitas barang dan jasa yang ditawarkan kepada masyarakat, khususnya terkait jaminan kehalalannya mengingat mayoritas penduduk Indonesia beragama Islam. Selain itu, perlu ada pendampingan pelaku Usaha Mikro, Kecil dan Menengah (UMKM) dalam proses sertifikasi halal mengingat terdapat 57, 83 juta pelaku UMKM (pada tahun 2018) yang menjadi mayoritas pelaku usaha di Indonesia. Dengan edukasi dan pendampingan ini, diharapkan Indonesia mampu bergeser dari negara konsumen produk halal menjadi negara produsen di masa mendatang.

\section{UCAPAN TERIMA KASIH}

Di akhir penulisan artikel ilmiah ini, penulis ingin menyampaikan ucapan terima kasih kepada seluruh pihak terkait atas kontribusinya dalam membantu penyelesaian penulisan penelitian ini. Khususnya pihak-pihak yang telah membantu memberikan informasi terkini terkait perkembangan industri halal di Indonesia, di antaranya adalah Bapak Rifqi Ismal, Ph.D dari Departemen Ekonomi dan Keuangan Syariah (DEKS) Bank Indonesia dan Bapak Deden Firman Hermansyah dari Direktorat Pengaturan dan Perizinan Perbankan Syariah Otoritas Jasa Keuangan (OJK). 


\section{Jurnal Ilmiah Ekonomi Islam, 6(03), 2020, 435}

\section{REFERENSI}

Akbar, C. (2019). "Konsumsi Produk Halal Di RI Tinggi, Bappenas: Kebanyakan Impor." TEMPO.CO.

Aziz, M., Rofiq, A., Ghofur, A.. 2019. "Regulasi Penyelenggaraan Jaminan Produk Halal Di Indonesia Perspektif Statute Approach.” ISLAMICA: Jurnal Studi Keislaman 14(1):15170.

CNN Indonesia. (2019). "KNKS Sebut Pertumbuhan Pangsa Pasar Keuangan Syariah Stagnan." CNN Indonesia.

Crescent Rating. (2019). "Global Muslim Travel Index 2019." Global Muslim Travel Index.

Cahyani, D. I., \& Sumadi, S. (2015). Alternatif Sistem Ekonomi Islam Untuk Indonesia Yang Lebih Sejahtera. Jurnal Ilmiah Ekonomi Islam, 1(02).

Erwina, T., Haryadi, H., Mustika, C. (2018). "Pengaruh Neraca Transaksi Berjalan, Transaksi Modal Dan Utang Luar Negeri Terhadap Cadangan Devisa Indonesia." E-Jurnal Perspektif Ekonomi Dan Pembangunan Daerah 7(2):57-70.

Fajaruddin. (2018). "Efektivitas Undang-Undang Nomor 33 Tahun 2014 Tentang Jaminan Produk Halal Dalam Perlindungan Konsumen." De Lega Lata: Jurnal Ilmu Hukum Fakultas Hukum UMSU 3(2):2014-16.

Faried, A.I. (2019). "Implementasi Model Pengembangan Industri Halal Fashion Di Indonesia." Jepa 4(2).

Indonesia Halal Lifestyle Center. (2019). "Indonesia Halal Economy and Strategy Roadmap 2018/19: A Preview." Indonesia Halal Lifestyle Center.

Jaelani, A. (2017). "Halal Tourism Industry in Indonesia: Potential and Prospects." SSRN Electronic Journal 7(3).

Kartika, A.F. (2020). "Fenomena Label Halal Is It a Awareness or Branding." Jurnal Ilmiah Ekonomi Islam 6(1):87.

Kementerian Keuangan Republik Indonesia. (2019). "Media Keuangan." Kementerian Keuangan 14(140).

Kurniawati, D.A., Savitri, H. (2019). "Awareness Level Analysis of Indonesian Consumers toward Halal Products." Journal of Islamic Marketing 11(2):522-46.

Kusnadi, M. (2019). "Problematika Penerapan Undang-Undang Jaminan Produk Halal Di Indonesia." Islamika: Jurnal Keislaman Dan Ilmu Pendidikan, 1(2):116-32.
Nasrullah, A. (2018). "Analisis Potensi Industri Halal Bagi Pelaku Usaha Di Indonesia." At-Tahdzib: Jurnal Studi Islam Dan Muamalah 6(1):50-78.

Neuman, W.L., Djamba, Y.K. (2014). Social Research Methods: Qualitative and Quantitative Approaches. 7th ed. USA: Pearson.

Nusran, M., Gunawan, M., Razak, S.N., Wekke, I.S. (2018). "Halal Awareness on the Socialization of Halal Certification." IOP Conference Series: Earth and Environmental Science 175.

Otoritas Jasa Keuangan. (2019). Laporan Perkembangan Keuangan Syariah 2018. Jakarta: Otoritas Jasa Keuangan.

Permana, A. (2019). "Tantangan Dan Peluang Industri Halal Di Indonesia Dan Dunia." Institut Teknologi Bandung.

Pryanka, A. (2018). "Ini Tantangan Dongkrak Industri Halal Di Indonesia." Republika Online.

Purba, N. (2016). Analisis Faktor-Faktor Yang Mempengaruhi Cadangan Devisa Di Indonesia. Medan: Universitas Negeri Medan.

Randeree, Kasim. (2019). "Demography, Demand and Devotion: Driving the Islamic Economy." Journal of Islamic Marketing.

Redaksi FIN. (2019). "Ekspor Produk Fashion Muslim Tembus USD 9,2 Miliar." Fajar Indonesia Network.

Sayoga, P., Tan, S. (2017). "Analisis Cadangan Devisa Indonesia Dan Faktor-Faktor Yang Mempengaruhinya." Jurnal Paradigma Ekonomika 12(1):25-30.

State of Global Islamic Economy Report. (2019). State of Global Islamic Economy Report 2019/20. New York: Thomson Reuters.

Subarkah, AR.. (2018). "Potensi Dan Prospek Wisata Halal Dalam Meningkatkan Ekonomi Daerah (Studi Kasus: Nusa Tenggara Barat)." Sospol: Jurnal Sosial Politik 4(2):49-72.

Tim Publikasi Katadata. (2020). "Industri Halal Untuk Semua." Kata Data.

Yasid, F.F., Andriansyah, Y. (2016). "Factors Affecting Muslim Students Awareness of Halal Products in Yogyakarta, Indonesia." International Review of Management and Marketing 6(S4):27-31. 